\title{
Cutaneous Melanoma cM1a TNM Finding v8
}

National Cancer Institute

\section{Source}

National Cancer Institute. Cutaneous Melanoma cM1a TNM Finding v8. NCI Thesaurus. Code C136897.

Cutaneous melanoma with distant metastasis to skin, soft tissue including muscle, and/or nonregional lymph node. LDH level not recorded or unspecified. (from AJCC 8th Ed.) 